\title{
Effect of Different Treatments on Seed Germination of Honey Locust (Gleditschia triacanthos)
}

\author{
Marzieh Babashpour Asl (Corresponding author) \\ Department of Horticultural Science \\ Islamic Azad University of Maragheh Branch \\ PO box 345 Maragheh, East Azarbaijan, Iran \\ Tel: 91-43-015-052Ｅ-mail: babashpour@iau-maragheh.ac.ir
}

\author{
Raana Sharivivash \\ Department of Horticultural Science \\ Islamic Azad University of Maragheh Branch \\ PO box 345 Maragheh, East Azarbaijan, Iran
}

Tel: 91-49-209-730 E-mail: raana_sv@yahoo.com

\author{
Akram. Rahbari \\ Department of Horticultural Science \\ Islamic Azad University of Maragheh Branch \\ PO box 345 Maragheh, East Azarbaijan, Iran \\ Tel: 91-41-773-819 E-mail: nasrinrahbary@yahoo.com
}

\begin{abstract}
Honey-locust (Gleditschia triacanthos) seeds, like those of many leguminous species, have hard and impermeable coats. Germination is thought to be enhanced when seeds are scarified or soaked in concentrated sulfuric acid or hot water. This experiment was separated into two parts: Scarification methods and stratification investigation. The result from the first experiment showed that acid scarification treatment for 1 hour was the best method for breaking their dormant period. However in the second experiment it was found that the honey locust seeds like those of many leguminous species do not have dormant embryo, because stratification did not affect seed germination and there was no significant difference between stratification treatment and control. It can be concluded that acid scarification without stratification is optimized in breaking honey-locust seed dormancy.
\end{abstract}

Keywords: Honey-locust, Germination, Stratification, Scarification, Dormancy

\section{Introduction}

Gleditschia triacanthos (Honey locust) is deciduous tree that is useful for windbreaks, shelterbelts, erosion control, wildlife food, and local wood products (posts and railroad ties) (Blair, 1990). Honeylocust is used for buffer strips along highways or in urban forests, where it can be successfully grown in areas with air pollution, poor drainage, salty soils, and drought (Ertekin \& Kirdar, 2010). Honey locust has also become highly valued as an agro-forestry species in other parts of the world (Davies and Macfarlane, 1979; Felker and Bandurski, 1979). This dicot plant is native to the U.S. and has its most active growth period in the spring and summer (Vine, 1960). Honey-locust fruits are flat, indehiscent, often twisted legumes (pods) 15 to $41 \mathrm{~cm}$ in length (Blair, 1990). The small flat, brownish seeds, 8 to $12 \mathrm{~mm}$ in length, are embedded in a sweet pulp, the feature that attracts livestock and wildlife to the fruits (Vines, 1960). The legumes may have up to 12 seeds. These legume and seed characteristics are the best way to distinguish between species (Brown and Kirkman, 1990). The seeds are close to the same size and contain a thin, flat embryo surrounded by a layer of horny endosperm. The hard seed coats of honey-locust must be treated to make them permeable before germination can occur (Heit, 1942; Liu and et al, 1981). Various chemical and mechanical treatments are used to overcome hard or impervious seed coats so that the imbibition of water and exchange of gases necessary for germination can occur. For chemical treatment, seeds can be soaked in concentrated grade $\mathrm{H}_{2} \mathrm{SO}_{4}$ and for mechanical treatment, for example, dried seeds are 
taken and placed in metal container with gravels. The container is vigorously shaken so that the gravels scratch the seed epicarp (Usberti and Martines, 2007). In nature, scarification often occurs by fall seeding. Freezing temperatures or microbial activities modify the seed coat during the winter. Scarification can also occur as seeds pass through the digestive tract of various animals. Scarification can also be forced, rather than waiting for nature to alter the seed coats. Commercial growers scarify seeds by soaking them in concentrated sulfuric acid. Seed coats can also be filed with a metal file, rubbed with sandpaper, nicked with a knife, cracked gently with a hammer to weaken the seed coat or soaked in hot water. Following scarification, the seeds should be dull in appearance, but not deeply pitted or cracked as to damage the embryo. Scarified seeds do not store well and should be planted as soon as possible after treatment (Young, 1992).

Seed collected while they are slightly immature will have thinner seed coats and can often be germinated without any pretreatment. This practice is not recommended, however, because the immature seed coats are not effective barriers against disease. Soaking the seeds in either concentrated sulfuric acid or hot water has been used. Soaking time in acid must be determined for each seed lot because of variation in seed coat hardness due to genetic or developmental differences (Bonner, 1974). This study was designed to test two hypotheses. The first hypothesis was to test whether the germination was inhibited by physical dormancy which could be improved by methods of scarification. The second hypothesis was to test whether the germination was inhibited by physiological dormancy which can be improved by methods of stratification. The objectives of the study were to determine: 1) the effects of scarification and 2) the effects of stratification on germination of honey-locust seeds.

\section{Materials and Methods}

\subsection{Experiment 1}

Fully mature fruits of honey-locust (Gleditschia triacanthos) were collected from Tabriz in East Azerbaijan province (North West of Iran, Latitude $38^{\circ} 05^{\prime} \mathrm{N}$, Longitude $46^{\circ} 17^{\prime} \mathrm{E}$, Altitude $1360 \mathrm{~m}$ above sea level) in December. The fruits were air-dried for two days at room temperature, after which seeds separated manually. Uniform (as far as possible) seeds were treated with Captan fungicide. There were five scarification treatments that tested the physical dormancy hypothesis and consisted of three acid treatments, one hot water and a control treatment (untreated seeds). 450 seeds were selected. For acid treatment, 270 seeds were soaked in concentrated sulfuric acid for 1, 2 and 3 hours ( 90 seeds were used for each treatment). Thereafter, they were washed thoroughly with tap water. For hot water treatment, 90 seeds were placed in 3 to 4 times their volume of water $\left(90^{\circ} \mathrm{C}\right)$. Seeds and water are allowed to cool to room temperature. The experiment utilized a Completely Randomized Design (CRC) with two replications. 30 seeds were planted in a tray filled with potting soil/leaf mold growing medium. The seeds were planted at the same time and kept in a growth room with temperature between $20^{\circ} \mathrm{C}-25^{\circ} \mathrm{C}$ and trays were watered with tap water according to need. Seed germination was recorded daily, the radical emergence $(2-5 \mathrm{~mm})$ serving as an index of germination. The germination percentage and germination rate were calculated. Germination rate was calculated according to the formula described by Maguirw (1962) and (Esechie) (1994) as follows:

$$
\mathrm{GR}=\Sigma \frac{S i}{D i}
$$

$\mathrm{S}_{\mathrm{i}}=$ total number of germinated seeds

$\mathrm{D}_{\mathrm{i}}=$ number of days per counting

$\mathrm{n}=$ counting frequency

Also number of days to $50 \%$ germination (T50) and root length (mm) were recorded.

\subsection{Experiment 2}

Seeds were prepared like experiment 1 . There were four treatments in this experiment consisting of two cold stratification treatments and one cold stratification treatment of acid scarified seeds and one control treatment (90 untreated seeds, 30 seeds for each replication). 360 seeds were selected. For cold stratification treatment, 180 non-scarified seeds were kept at $5 \pm 1^{\circ} \mathrm{C}$ for 4 and 10 weeks. For third treatment, 90 seeds were soaked in concentrated sulfuric acid for 2 hours were used. Thereafter, they were kept at $5 \pm 1^{\circ} \mathrm{C}$ for 10 weeks. For stratification, seeds were put into plastic bags filled with vermiculite and watered with tap water according to need.

\subsection{Statistical analysis}

The data were analyzed using the SAS software and the means were compared with Duncan's Test at $\mathrm{p}=0.05$. 


\section{Results}

\subsection{Scarification}

The acid scarification treatments significantly $(\mathrm{P}<0.05)$ increased germination percentage of honey-locust seeds compared to the hot water and control in experiment 1 (Table 1). There were no significant difference between hot water treatment and control (Table 2). Also the acid scarification treatments significantly $(\mathrm{P}<0.05)$ increased germination rate, number of days to $50 \%$ germination (T50) and root length (mm) of honey-locust seeds compared to the hot water and control.

No germination was recorded from seeds in the control for period of the experiment.

The fact that concentrated sulphuric acid for 3 hours gave the highest percentage germination $(86.67 \%)$ and within the shortest period as compared 1 and 2 hours, indicate that the more rapidly the seed coat is ruptured the faster the rate of germination, however, prolonged Emerson may be injurious to the seeds as the acid may rapture vital parts of the embryo. Sulphuric acid is thought to disrupt the seed coat and expose the lumens of the macrosclereids cells, permitting imbibitions of water (Nikoleave, 1977) which trigger germination. The treatment with sulphuric acid for 1 and 2 hours gave $61.11 \%$ and $78.89 \%$ germination, respectively. However there were no significant differences between 3 levels of sulphuric acid.

\subsection{Stratification}

The stratification and combinational treatment with scarified seeds significantly $(\mathrm{P}<0.05)$ increased germination percentage of honey-locust seeds compared to control (Table 3). There were no significant differences between combinational treatment and control (Table 4). Also the stratification treatment for 4 weeks significantly $(\mathrm{P}<0.05)$ increased germination rate $(0.0423)$ and root length $(2.39 \mathrm{~mm})$ of honey-locust seed compared to the other treatments. No germination was recorded from seeds in the stratification treatment for 10 weeks. However, $6.67 \%$ for germination percentage and 0.0423 and 2.39 for germination rate and root length respectively, are not acceptable numbers for germination of seeds. So, the stratification did not affect germination of honey-locust seeds.

\section{Discussion}

Seed dormancy is a means to allow seeds to initiate germination when conditions are normally favorable for germination and survival of the seedlings. Dormancy can be regulated by the environment or by the seed itself. The seed dormancy may be due to unfavorable environmental conditions or sometimes, some seeds may not germinate because of some inhibitory factor of the seed itself. Dormancy of seed due to inhibitory factors, are either due to hard seed coat (external) or physical of physiological status of the interior of the seed. Seed dormancy in Honey locust (Gleditschia triacanthos) belongs to the first type.

Acid scarification is known to be highly effective in improving germination of species with hard seed coats (Youssef, 2008). The results demonstrate that the most effective method of improving the germination of honey-locust seed proved to be acid scarification. This indicates that the low germination of honey-locust is probably due to physical dormancy which was consistent with the results from previous research done on the legume species Galactia elliottii (Muir and Pitman, 1987) and Medicago sativa subsp.falcata (Xu and Bou, 2004). Many leguminous seeds have wide dormancy durations induced by the appetence of a hard waterproof coat, but the nature of the hard coat related dormancy is specifically. The blocking of water access into the seed is the most common cause of delay in seed germination (Ballard, 1973; Rolston, 1987; Cavanagh, 1980)

The stratification treatments did not show a consistent response indicating that the low germination of honey-locust was probably not due to physiological dormancy. These results support the findings of previous research on the freezing and thawing of other leguminous seeds which reported that freezing seeds to $-20^{\circ} \mathrm{C}$ had little to no effect on germination (Busse, 1930). However, colder temperatures and longer durations have shown to increase germination in sweet clover (Melilotus sp.) and purple-flowered alfalfa (Medicago sativa) seeds (Busse, 1930). Further research could be done experimenting with different cold temperatures and durations.

Although hot water treatment had no effect on germination in this study, further experimentation with treatments at different temperatures might produce different results.

\section{Conclusions}

The best efficiency method for breaking dormancy of Gleditschia triacanthos seeds was acid scarification method that soaking in concentrated sulphuric acid for 1 hour. 


\section{References}

Ballard, L.A.T. (1973). Physical barriers to germination. Seed Science and Technology, 1: $285-303$.

Blair, RM. (1990). Gleditsia triacanthos L., honeylocust. In: Burns RM, Honkala BH, tech. coords. Silvics of North America. Volume 2, Hardwoods. Agric. Handbk. 654. Washington, DC: USDA Forest Service: 358 B364.

Bonner, F.T., Burton J.D., \& Grigsby H.C. (1974). Gleditsia L., honeylocust. In: Schopmeyer CS, tech. coord. Seeds of woody plants in the United States. Agric. Handbk. 450. Washington, DC: USDA Forest Service: 431B433.

Brown, C.L., \& Kirkman, L.K. (1990). Trees of Georgia and adjacent states. Portland, OR: Timber Press. 292 p. Busse, W. F. (1930). Effect of Low Temperatures on Germination of Impermeable Seeds. Botanical Gazette 89(2):169-179.

Cavangh, A.K. (1980). A review of some aspects of the germination of Acacias. Proceedings. of the Royal Society of Victoria, 91: 161-180.

Davies, D.J.G., \& Macfarlane, R.P. (1979). Multiple-purpose trees for pastoral farming in New Zealand: with emphasis on tree legumes. New Zealand Agricultural Science. 13(4): 177B186 [Forestry Abstracts 42(1): 252; $1981]$.

Ertekin, M., \& Kirdar, E. (2010). Effects of seed coat colour on seed characteristics of honeylocust (Gleditsia triacanthos). Afr. J. Agric. Res., 5(17): 2434-2438.

Fredan, M.A.A., \& Ali, Y.S.S. (2008).Seed Scarification Requirement in Doum (Hyphaene thebaica Mart.). Sci. J. of King Faisal University (Basic and Applied Sciences) 9(2): 75-84.

Heit, C.E. (1942). Acid treatment of honey locust. Notes For. Invest. 42. Albany: New York Conservation Department. np.

Muir, J. P., \& Pitman W.D. (1987). Improving Germination Rate of the Florida Legume Galactia elliottii. Journal of Range Managemen.t 40(3):452-454.

Nikoleave, M.G. (1977). Factors controlling seed dormancy pattern. North Holland publishing Co, Amsterdam, pp. 51-74.

Roleston, M.P. (1978). Water impermeable seed dormancy. Botanical review, 44:365-396.

Usberti, R., \& Martines, L. (2007). Sulfuric acid scarification effects on Brachiaria brizantha, B. humidicola and Panicum maximum seed dormancy release. Revista Brasileira de Sementes, 29(2): 143-147.

Vines, R.A. (1960). Trees, shrubs, and woody vines of the Southwest. Austin: University of Texas Press. 1104 p.

Xu, L., Boe A., Johnson, P. S., \& Kephart, K. (2004). Effects of a Naturalized Population of Yellow-flowered Alfalfa (Medicago sativa ssp. facata) on Species Richness and Biomass Production of Native Rangeland. p99-105 In: Beef Cattle Research Report, SDSU, Brookings, SD

Young, J. A., \& Young, C.G. (1992). Seeds of Woody Plants in North America. Revised and enlarged edition. Dioscorides Press, Portland, OR. (This is the most complete and useful book on woody plant seeds and their germination requirements - a "must have" for any woody plant propagation library.)

Youssef, A.M. (2008). Adaptive responses of some desert plants from different ecosystems of Suez road, Egypt. Res. J. Agric. Biol. Sci., 4(5): 595-603.

Table 1. ANOVA for honey locust seed germination (Experiment 1)

\begin{tabular}{cccccc}
\hline \multirow{2}{*}{$\begin{array}{c}\text { Source of } \\
\text { variation }\end{array}$} & d.f. & \multicolumn{4}{c}{ Means of Squares } \\
\cline { 3 - 6 } & 4 & $4653.931^{*}$ & $1.635^{*}$ & $235.767^{*}$ & $286.773^{*}$ \\
\hline treatments & 10 & 184.469 & 0.065 & 0.867 & 51.442 \\
\hline SD & percentage & Termination \\
rate
\end{tabular}

$*=$ statistically significant at $0.05 \%$ probability level. 
Table 2. Effect of acid scarification and hot water treatments on different parameters of seed germination of Honey-locust

\begin{tabular}{cccccc}
\hline Treatments $\longrightarrow$ & Control & $\mathrm{H}_{2} \mathrm{SO}_{4}$ (1 hour) & $\mathrm{H}_{2} \mathrm{SO}_{4}$ (2hour) & $\mathrm{H}_{2} \mathrm{SO}_{4}$ (3hour) & Hot water $\left(90^{\circ} \mathrm{C}\right)$ \\
\hline $\begin{array}{c}\text { Germination } \\
\text { percentage }\end{array}$ & $0^{\mathrm{b}}$ & $61.11^{\mathrm{a}}$ & $78.89^{\mathrm{a}}$ & $86.67^{\mathrm{a}}$ & $12.22^{\mathrm{b}}$ \\
\hline Germination rate & $0^{\mathrm{b}}$ & $1.15^{\mathrm{a}}$ & $1.48^{\mathrm{a}}$ & $1.63^{\mathrm{a}}$ & $0.23^{\mathrm{b}}$ \\
\hline T50 & $0^{\mathrm{c}}$ & $19.00^{\mathrm{a}}$ & $14.33^{\mathrm{ab}}$ & $14.00^{\mathrm{b}}$ & $0^{\mathrm{c}}$ \\
\hline Root length $(\mathrm{mm})$ & $0^{\mathrm{c}}$ & $20.87^{\mathrm{a}}$ & $21.20^{\mathrm{a}}$ & $18.57^{\mathrm{ab}}$ & $5.79^{\mathrm{bc}}$ \\
\hline
\end{tabular}

In each row or column, means with the similar letter(s) are not significantly different at $5 \%$ level of probability using Duncan' Test.

Table 3. ANOVA for honey locust seed germination (Experiment 2)

\begin{tabular}{|c|c|c|c|c|c|}
\hline \multirow{2}{*}{$\begin{array}{l}\text { Source of } \\
\text { variation }\end{array}$} & \multirow[b]{2}{*}{ d.f. } & \multicolumn{4}{|c|}{ Means of Squares } \\
\hline & & $\begin{array}{l}\text { Germination } \\
\text { percentage }\end{array}$ & $\begin{array}{l}\text { Germination } \\
\text { rate }\end{array}$ & T50 & $\begin{array}{c}\text { Root } \\
\text { length }(\mathrm{mm})\end{array}$ \\
\hline treatments & 3 & $28.06^{*}$ & $0.001^{*}$ & 0 & $3.03^{*}$ \\
\hline SD & 8 & 10.19 & 0 & 0 & $51 / 442$ \\
\hline
\end{tabular}

$*=$ statistically significant at $0.05 \%$ probability level.

Table 4. Effect of acid scarification and hot water treatments on different parameters of seed germination of Honey-locust

\begin{tabular}{|c|c|c|c|c|}
\hline $\begin{array}{l}\text { Treatments } \longrightarrow \\
\text { Parameters } \downarrow\end{array}$ & Control & $\begin{array}{l}\text { Stratification (4 } \\
\text { weeks) }\end{array}$ & $\begin{array}{l}\text { Stratification (10 } \\
\text { weeks) }\end{array}$ & $\begin{array}{c}\mathrm{H}_{2} \mathrm{SO}_{4} \text { (3hour) }+ \\
\text { Stratification (10 weeks) }\end{array}$ \\
\hline $\begin{array}{l}\text { Germination } \\
\text { percentage }\end{array}$ & $1.11^{\mathrm{ab}}$ & $6.67^{\mathrm{a}}$ & 0 & $4.44^{\mathrm{ab}}$ \\
\hline Germination rate & $0.0073^{\mathrm{ab}}$ & $0.0423^{\mathrm{a}}$ & 0 & $0.0273^{a b}$ \\
\hline $\mathrm{T} 50$ & 0 & 0 & 0 & 0 \\
\hline Root length $(\mathrm{mm})$ & $0.71^{\mathrm{ab}}$ & 2.39 & 0 & $0.95^{\mathrm{ab}}$ \\
\hline
\end{tabular}

In each row or column, means with the similar letter(s) are not significantly different at $5 \%$ level of probability using Duncan' Test. 